内視鏡下鼻副鼻腔手術中の疼痛評価

\author{
高橋 淳人・庄司 和彦・児嶋 剛 \\ 伊木 健浩・水田 匡信
}

\title{
Intra-Operative Pain during Endoscopic Sinus Surgery under Local Anesthesia
}

\author{
Atsuhito Takahashi, Kazuhiko Shoji, Tsuyoshi Kojima, \\ Takehiro Iki and Masanobu Mizuta \\ (Tenri Hospital)
}

\begin{abstract}
Endoscopic sinus surgery (ESS) is a well-documented procedure that has been used worldwide. Patients can undergo surgery under either local or general anesthesia. Under local anesthesia, one of the important issues for patients is the degree of intra-operative pain. We should perform the procedure without causing unbearable pain. This study evaluated the degree of intra-operative pain during ESS under local anesthesia and the ability of patients to cope with unbearable pain. Twenty-one patients were entered into this study (10 men, 11 women) operated by one surgeon between March 2006 and June 2007. During the first 9 months, 11 patients underwent the procedure without the maxillary nerve block. During the next 7 months, 10 patients were managed with the maxillary nerve block. The severity of pain was scored by the patient on a numerical rating scale (NRS). Pain severity was indicated by the number (minimum 0 and maximum 5).

Eleven patients without the block reported pain during of the opening maxillary sinus (average of score 2. 91). However 10 patients with the block reported that there was little pain (score average 0.95 ). The difference between the two groups was significant. We confirmed the degree of the intra-operative pain during ESS and that pain could be successfully managed by maxillary nerve block. NRS is a useful tool to evaluate intra-operative pain under local anesthesia, because we can hear a report of the pain score even without visually monitoring the tool (NRS).
\end{abstract}

Key words : intra-operative pain, endoscopic sinus surgery (ESS), maxillary nerve block, numerical rating scale (NRS)

\section{はじめに}

内視鏡下鼻副鼻腔手術 (endoscopic sinus surgery：ESS) は局所麻酔下に行うことが十分可能であり，当科ではほ ぼ全例局所麻酔下に手術を行っている，局所麻酔下の手 術については術中疼痛のコントロールが重要であるが, われわれの渉猟しえた限りではESSの手術手順ごとに術 中疼痛の程度をペインスケールなどを用いて検討した報 告はなく，経験上上顎洞膜様部開放時に疼痛を訴える症
例を多く認めていたものの，実際どの手順でどの程度の 疼痛をきたすかは明らかではなかった。

当科では，耳鼻咽喉科診療に㧍ける疼痛を簡便な数字 のペインスケール (numerical rating scale : NRS) (図 1) を用いて評価している．われわれはこれまで口蓋扁桃摘 出術の術後疼痛についてNRS を用いて, 大人と子供で術 後疼痛に差があることや大人の症例で術後疼痛にリバウ

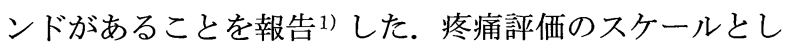




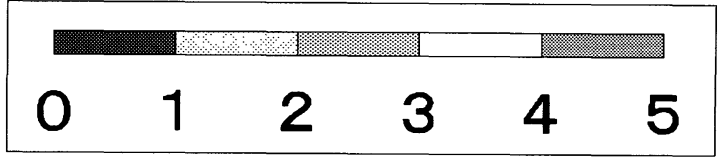

0点:痛みが全くない状態 5点:想像できる最も強い痛み

図 1 Numerical Rating Scale (NRS)

ては visual analogue scale（VAS）が代表的であるが，疼 痛の程度の聴取においては必ずスケール自体を提示して 使用しなければならないが，NRS は理解しやすく，ス ケール自体を提示しなくても疼痛の程度を聴取可能で局 所麻酔下手術の術中疼痛の評価に使用できる.

今回 NRS を用いて局所麻酔にて行った ESS の術中疼 痛を評価し，さらに上顎神経ブロックの施行の有無での 術中疼痛の変化を検討し報告する.

\section{対象}

対象は平成 18 年 3 月から平成 19 年 6 月の間に同一術 者（著者）が局所麻酔下に ESS により上顎洞篩骨洞手術 を執刀し, 術中疼痛を聴取した 21 例で男性 10 名（13〜 77 歳, 平均 53 歳), 女性 11 名 $(27 \sim 63$ 歳, 平均 50 歳) であった. 平成 18 年 3 月から 11 月に手術を施行した 11 例（男性 4 例，女性 7 例）は上顎神経ブロックを施行せ
ずに手術を行った（ブロックなし群とする）。平成 18 年 12 月から平成 19 年 6 月に手術を施行した 10 例（男性 6 例, 女性 4 例）は上顎神経ブロックを施行し手術を行っ た (ブロック群とする)。手術適応疾患は, 慢性副鼻腔炎 18 例, 副鼻腔真菌症 3 例であった。

\section{方 法}

局所麻酔下に内視鏡下上顎洞篩骨洞手術を施行し, Numerical rating scale（NRS）を用いて手術手順ごとに疼 痛の程度を術中に術者が聴取した。ペインスコア聴取の 時点（図 2）は，(1)術前に病棟での $4 \%$ キシロカイン ${ }^{\circledR}$. $0.1 \%$ ボスミン ${ }^{\circledR}$ 付タンポンガーゼ挿入 (表面麻酔), (2) 執刀 30 分前の上顎神経ブロック (ブロック群のみ), (3) $10 \%$ コカイン外用液の鼻腔内塗布，(4)鼻提，中鼻道外側 への $1 \% \mathrm{E}$ キシロカイン ${ }^{\circledR}$ の局所麻酔（浸潤麻酔），(5)中 鼻道ポリープ切除, (6)鈎状突起切開, (7)前篲骨洞開放, (8)上顎洞膜様部開放 (以下，上顎洞開放），9術後鼻内夕 ンポン挿入 ${ }^{2)}$ (アルゴダーム ${ }^{\circledR}$ ) の 9 点で聴取した. 両鼻 腔の手術を行った例は CT で病変が高度である側のスコ アを聴取した. 当科にて作成した NRS は 0 から 5 までの 整数を印し, その上に青, 水色, 緑, 黄, 赤の 5 色を配 置したもの（図 1) で「痛みがまったくない」を 0 ,「想 像できるもっとも強い痛み」を 0 とし， 0.5 刻みも可 (11 段階）とした.

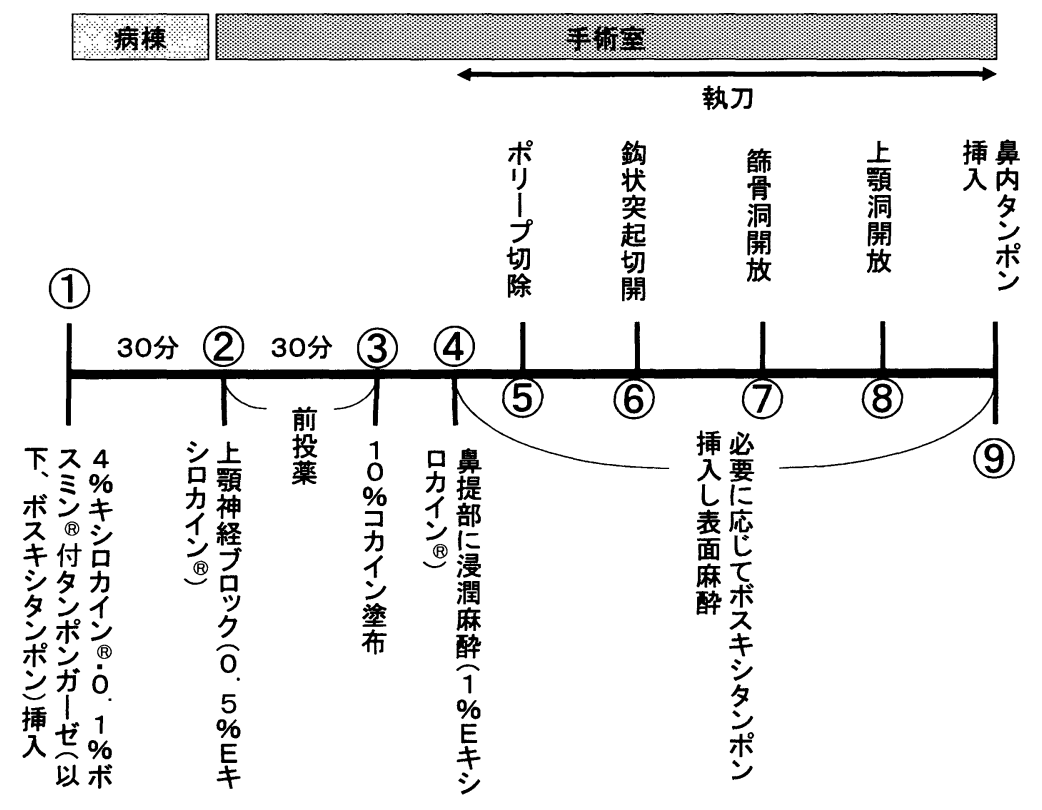

図 2 ペインスコア聴取の時点と局所麻酔の方法 
上顎神経ブロックの有無でのペインスコアの差の検定 には, Mann-Whitney U 検定を用いた。

\section{麻酔の方法}

手術室入室 30 分前に $4 \%$ キシロカイン ${ }^{\circledR}, 0.1 \%$ ボスミ ン®付タンポンガーゼ（以下，ボスキシタンポン）を中 鼻道および総鼻道に片側鼻腔あたり計 3 本挿入し, 執刀 まで約 1 時間の表面麻酔を施す。手術室入室後，ブロッ ク群では上顎神経ブロックとして翼口蓋窩に $0.5 \% \mathrm{E}$ キ シロカイン® ${ }^{\circledR} 23 \mathrm{G}$ カテラン針にて片側あたり $10 \mathrm{ml}$ 浸 潤させる. 10\%コカインは中鼻道, 嗅裂を中心に鼻腔全 体に綿棒で塗布する（片側 $0.5 \mathrm{ml}$ 程度）。最後に鼻提, 中鼻道外側に $23 \mathrm{G}$ カテラン針にて $1 \% \mathrm{E}$ キシロカイン ${ }^{\circledR}$ （片側 3〜 4 ml）を浸潤麻酔として局注する. その後は疼 痛の訴えに応じてボスキシタンポンで表面麻酔を行いな がら手術を行う。なお，上顎神経ブロックは煩骨弓中央 で約 $1 \mathrm{~cm}$ 足側から外眼角へ向けて穿刺する方法6) 8) (図 3）で施行した．穿刺針と皮膚面のなす角はおよそ 80 度 で, $4 \sim 5 \mathrm{~cm}$ 刺入するが神経に穿刺し鼻翼部や上口唇部 に放散痛を生じればそこから $5 \mathrm{~mm}$ ほど針を抜いて局所 麻酔薬を注入する.X 線透視や撮影は行っていないが, $10 \mathrm{ml}$ の $0.5 \% \mathrm{E}$ キシロカイン ${ }^{\circledR}$ を翼口蓋窩に投与する ことによって上顎神経やその分枝に十分浸潤麻酔できる と考えている. 当科の前投薬は比較的軽いものでアタ ラックス $\mathrm{P}^{\circledR} 25 \mathrm{mg}$, 硫酸アトロピン ${ }^{\circledR} 0.5 \mathrm{mg}$ を生理食塩 水 $100 \mathrm{ml}$ に混注して 30 分程度で点滴静注した.

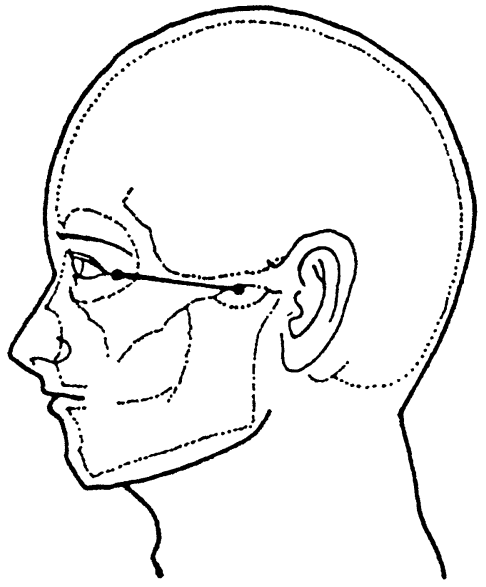

図 3 上顎神経ブロック

外眼角と刺入点を結ぶ誘導線を示す。ブロック針は皮膚 面に対しておよそ 80 度の角度で刺入する。

\section{結 果}

個々の症例の術中ペインスコアを表にして示す．表 1 はブロックなし群の結果であり, 表 2 はブロック群の結 果である. スコア 3 以上を太字で表記し，平均值を表の 最下段に示す。

術前表面麻酔ガーゼ挿入は上顎神経ブロックの有無に かかわらず，スコア 2 前後であった。 上顎神経ブロック 時の疼痛はスコア 2.4 であった。 上顎神経ブロックの有 無にかかわらず, コカイン液塗布, 浸潤麻酔, ポリープ 切除，鈎状突起切開時の疼痛の平均值は 1.5 以下であっ

表 1 ブロックなし群の術中疼痛

\begin{tabular}{|c|c|c|c|c|c|c|c|c|}
\hline 年齢／性別 & 術前表面麻酔 & コカイン塗布 & 浸潤麻酔 & ポリープ切除 & 鈎状突起切開 & 篩骨洞開放 & 上顎洞開放 & タンポン挿入 \\
\hline 23/男 & 2 & 2 & 1 & & 2 & 4 & 4 & 3 \\
\hline 13/男 & 2 & & 1 & 1 & 1 & 1 & 2 & 1 \\
\hline 77/男 & 2 & 2 & 0 & 0 & 1 & 1 & 2 & 1 \\
\hline 45/男 & 1.5 & 1 & 1.5 & 2.5 & 1.5 & 1 & 3 & 1.5 \\
\hline 38/女 & 3 & 1 & 1 & & 1 & 1 & 2 & 1 \\
\hline 49/女 & 2 & 1 & 1 & & 1 & 2 & 3 & 1 \\
\hline 69/女 & 2 & 0 & 0 & 0 & 0 & 0 & 2 & 1 \\
\hline 46/女 & 3 & 2 & 0 & & 1 & 1 & 4 & 1 \\
\hline 43/女 & 3 & 2 & 3 & 2 & 2 & 3 & 3 & 2 \\
\hline 43/女 & 0.5 & 1 & 1 & 2 & & 2 & 3 & 2 \\
\hline 43/女 & 4 & 0 & 0 & & 0 & 1 & 4 & 0 \\
\hline 平均値 & 2.27 & 1.20 & 0.86 & 1.25 & 1.05 & 1.55 & 2.91 & 1.32 \\
\hline
\end{tabular}


表 2 ブロック群の術中疼痛

\begin{tabular}{|c|c|c|c|c|c|c|c|c|c|}
\hline 年齢／性別 & $\begin{array}{c}\text { 術前表面 } \\
\text { 麻酔 }\end{array}$ & ブロック & $\begin{array}{c}\text { コカイン } \\
\text { 塗布 }\end{array}$ & 浸潤麻酔 & ポリープ & $\begin{array}{c}\text { 鈎状突起 } \\
\text { 切開 }\end{array}$ & $\begin{array}{l}\text { 節骨洞 } \\
\text { 開放 }\end{array}$ & $\begin{array}{l}\text { 上顎洞 } \\
\text { 開放 }\end{array}$ & $\begin{array}{l}\text { タンポン } \\
\text { 插入 }\end{array}$ \\
\hline 75/男 & 4 & 3 & 2 & 4 & & 2 & 2 & 2 & 2 \\
\hline 56/男 & 0.5 & 2 & 1.5 & 0 & & 0 & 0 & 0 & 0 \\
\hline 55/男 & 2 & 4 & 0.5 & 0 & 0 & 0 & 0 & 0 & 1 \\
\hline 70/男 & 1 & 2 & 5 & 5 & 0 & 0.5 & 0 & 0.5 & 0 \\
\hline 47/男 & 2 & 3.5 & 2.5 & 1 & 0.5 & 0.5 & 0 & 2 & 0 \\
\hline 69/男 & 1 & 1 & 1 & 0 & 0 & 0 & 0 & 1 & 0.5 \\
\hline 51/女 & 1.5 & 1.5 & 0 & 0 & 0 & 0 & 0 & 0 & 1 \\
\hline 63/女 & 5 & 4 & 2 & 4 & & 2 & 5 & 2 & 1 \\
\hline 56/女 & 2 & 2 & 0 & 0 & 0 & 0 & 0 & 1 & 0 \\
\hline 54/女 & 0 & 1 & 0 & 0 & 0 & 0 & 1 & 1 & 0 \\
\hline 平均値 & 1.90 & 2.40 & 1.45 & 1.40 & 0.07 & 0.50 & 0.80 & 0.95 & 0.55 \\
\hline
\end{tabular}

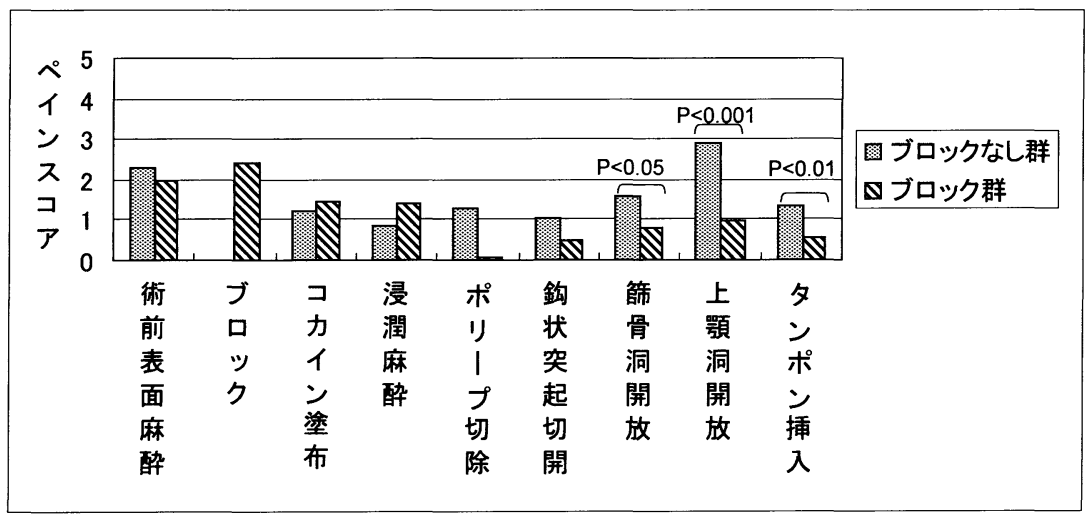

Mann-Whitney-U検定

図 4 平均値の検討（ブロックなし群 vs ブロック群）

た.

ブロックなし群では上顎洞開放時に 11 例中 7 例 (64 \%) でスコア 3 以上を示していた。 それに対しブロック 群では上顎洞開放時にスコア 3 以上を呈した例はみられ なかった. 平均值はブロックなし群で 2.91 であり, ブ ロック群では 0.95 とブロック群で低值であった (図 4). ブロックなし群では術前表面麻酔挿入時の疼痛より上顎 洞開放時の疼痛が強かった例が 11 例中 5 例（45\%）で あったのに対し，ブロック群では 10 例中 0 例（0\%）で あった. 篩骨洞開放はブロックなし群で 1.55 , ブロック 群で 0.8 でありブロック群で統計学的に有意に低值で あった. 術後鼻内タンポン挿入においてはブロックなし
群で 1.32 , ブロック群で 0.55 であり, ブロック群で有 意に低值であった。 上顎神経ブロックによって, 上顎洞・ 篩骨洞開放時の疼痛ならびに術後鼻内タンポン挿入時の 疼痛が有意に抑制できることがわかった. 上顎神経ブ ロックによる疼痛は 2.4 で, ブロックなし群での上顎洞 開放時の疼痛 2.91 より低值であった. なお上顎神経ブ ロックの合併症 (血腫, 散瞳, 複視) を生じた例はなかっ た.

\section{考察}

ESS は慢性副鼻腔炎などに対する患者への侵襲が少な い手術方法として現在広く普及している．手術は全身麻 
酔，局所麻酔のいずれでも可能であるが，局所麻酔下の 利点として，(1術中出血量が少ない314)，(2)術後の意識状 態がよいので，出血しても気道閉塞のリスクが低い，(3) 全身麻酔自体のリスクがない，などがあり，当科では ESS のほぼ全例を局所麻酔下に行っている，手術を受け ることに対する恐怖感や不安感を抱かない患者はほとん どいないと考えるが，局所麻酔下の手術を成功させるた めには, 術前説明を十分に行って恐怖感や不安を和らげ, さらに術中疼痛を十分にコントロールすることが重要で ある．局所麻酔下手術で耐えがたい疼痛を生じては，十 分な手術を行うことはできないし，ときに手術を中途断 念しなければならない可能性もある。よって疼痛の強い 場所や疼痛の程度を把握しておくことは非常に有用であ ると考える．これまでの手術経験から上顎洞開放時に強 い疼痛を生じることは実感していたが，われわれが渉猟 しえた限りではこれまでにESSの術中疼痛を詳細に報告 したものはなかった。当科ではオピオイド系鎮痛剤など の全身投与は傾眠や呼吸抑制などをきたすことがあり， 時に術後管理を困難にさせる可能性もあると考えてお り，麻酔前投薬としては軽いものではあるがアタラック ス $\mathrm{P}^{\circledR} 25 \mathrm{mg}$ および硫酸アトロピン ${ }^{\circledR} 0.5 \mathrm{mg}$ を生理食塩 水 $100 \mathrm{ml}$ に混注して 30 分程度で点滴静注している. 前 投薬による鎮痛効果がほとんど期待できないので，十分 な局所麻酔技術が要求される.

疼痛評価については，ある程度定量的な手法とし て visual analogue scale（VAS）をはじめとし，他に NRS (Numerical Rating Scale), VRS (Verbal Rating Scale), Face Scaleなどのペインスケールが知られている. VASは $10 \mathrm{~cm}$ の線分上に印をつけて疼痛を表現する. NRS は直線上に ある 0 から 5（10の場合むある）までの数字を用いて痛 みを表現する. VRS は痛みを言葉で表現したスケールで あり, Face Scale は痛みの程度を顔の表情で示したもの である. VAS，NRS，VRS の比較ではほぼ同じような反 応が得られるとされる5). ペインスケールの選択につい ては，(1)理解と管理がしやすい，(2)簡単である，(3)時間 がかからない，などの条件を満たすものが望まれる，小 児ではVAS，VRS は理解に難しいことがある．また高齢 者でもVAS の理解に難があるとされる. 当科ではペイン スケールとしてNRS が最も利用価值が高いと考え, 平成 16 年 3 月から耳鼻咽喉科診療における疼痛の評価をこの スケールにて行っている．これまでの使用経験上，NRS は幼稚園の小児から高齢者まで容易に使用できている。
さらにNRS以外のペインスケールはスケール自体を提示 しなければ疼痛の程度を聴取できない. しかし NRS はす ぐに理解でき，慣れるので，スケール自体を提示するこ となく疼痛の程度を聴取できる，術中疼痛をリアルタイ ムに聴取できることが, NRS の最大の利点であると考え る.

日常診療における疼痛を NRS にて評価してきた経験 上, スコア 3 以上はかなり強い疼痛であり, 術中疼痛は 少なくともスコア 3 未満に抑える必要がある。手術前に 病棟でのボスキシタンポン挿入が平均值でスコア 2 前後 であり, やや疼痛が強いと思われた。 特にポリープなど で鼻腔へのボスキシガーゼ挿入が困難な症例では, 無理 して入れずに手術室入室後にタンポンガーゼを入れ替え るなどの工夫が有用であると考える. コカイン液塗布に ついては，強い疼痛を訴えることは少ないが，嗅裂への 塗布時に疼痛を訴えることがある。浸潤麻酔，ポリープ 切除，鈎状突起切開は，上顎神経ブロックの有無で疼痛 の程度に差がなかったが，これは解剖的にガーゼ挿入が 容易であり，浸潤麻醉も施しやすいためと考えた．笠骨 洞は前部では強い疼痛を訴える患者はブロックの有無に かかわらず少なかったが，後部篩骨洞の開放時にブロッ クなし群にやや疼痛を訴える例が経験された，上顎洞開 放については，これまで経験的に自覚していたとおり， ブロックなし群ではスコア聴取を行った 9 点の内で最む 疼痛が強かった. スコア 3 以上の症例が 11 例中 7 例 (64 \%）であり，局所麻酔下手術を快適に行うには上顎洞開 放時の疼痛対策が必須であると考えた。 上顎神経ブロッ クを施行することによって，疼痛は平均值でスコア 1 以 下に抑えられており，スコア 3 以上の症例はなかった。 上顎神経ブロックは対応すべき上顎洞開放時の疼痛の軽 減に非常に有用であると思われた。後鼻神経のみのブ ロックでも上顎洞開放時の疼痛は抑えられる可能性はあ るが，その他の上顎神経枝の関与もありえると考え，当 科としては上顎神経ブロックが良いと考える.

上顎神経は正円孔を通り翼口蓋窩に出て翼口蓋神経, 上歯槽神経，煩骨神経に分枝する，上顎神経ブロックに ついてはこれまでさまざまな手技4)6) 99 が報告されてき た. 今回は煩骨弓中央で約 $1 \mathrm{~cm}$ 足側から外眼角へ向けて 穿刺する方法 ${ }^{6)} ＼mathrm{~ 8) ~ に て 行 っ た 。 ~ 一 般 に 上 顎 神 経 フ ゙ ロ ッ ~}$ クは $\mathrm{X}$ 線透視や撮影下に行うことが推奨されている778) が，神経に直接刺入することは強い痛みを伴うので，わ れわれは直接神経に当てずに神経近傍に $10 \mathrm{ml}$ の $0.5 \%$ 
Eキシロカイン®注射し, 執刀まで約 30 分置くことで上 顎神経およびその分枝に対してブロックの効果が十分期 待できると考えている. 実際本症例においても上顎洞開 放時の疼痛は良く抑えられていた. 上領洞真菌症で洞内 の真菌塊を除去するなど上顎洞の開放のみに留まらない 場合には，上顎神経ブロックはさらに有用であると考え る. 手術における神経ブロックは手術中のみの効果でよ く, 効果があれば目的の神経にピンポイントでブロック する必要はないと考える. 複視などの問題点もあるが, 局所麻酔薬の投与であり副作用も一時的であるので, 手 術における上顎神経ブロックではX線装置は不要である と考える. 今回篩骨洞開放時の疼痛も上顎神経ブロック にて抑制されていた。前頭洞, 笠骨洞, 蝶形骨洞の痛覚 については三叉神経第 1 枝（眼神経）のかかわりが多い といわれている ${ }^{10)}$. しかし鼻腔外側からの上顎神経の枝 のかかわりもある程度あると考える。眼神経ブロックも 上顎神経ブロックにあわせて行うことによってさらに術 中疼痛を軽減できると考えられるが，眼窩内に注射針を 刺入することにやや熟練を要し，眼窩内血腫や眼瞼部の 皮下出血斑を生じる可能性もある. 今回の結果からも内 視鏡下上顎洞節骨洞手術においては上顎神経のみのブ ロックで十分対応できると考えた。

\section{まとめ}

(1)局所麻酔下に施行した ESS の術中疼痛を NRS にて 評価し，報告した。

(2)上顎洞開放時の疼痛は強く,スコアは約 3 であった. 上顎神経ブロックを施行することによってスコアは 1 程 度に軽減できた。顎神経ブロックは簡便に施行でき, 術中疼痛に対し十分な軽減効果が期待できるので，局所 麻酔下に ESS を行う時には行うべき手技であると考え た.
(3) NRS は他のペインスケールとは異なり,スケール自 体を提示しなくてもスコアを聴取でき，局所麻酔下手術 の術中疼痛評価に有用である.

なお本論文の要旨は第 69 回耳鼻咽喉科臨床学会 (平成 19 年 7 月, 東京）にて発表した.

\section{参考文献}

1）高橋淳人, 庄司和彦, 池上 聰, 他 : ハーモニックスカル ペル®扁摘術の術後疼痛評価. 耳鼻臨床 98:881〜885, 2005.

2）池上 聰, 庄司和彦, 鈴木慎二, 他 : アルギン酸塩瀻維に よる術後鼻内パッキング. 耳鼻臨床 $98: 787 \sim 791 ， 2005$.

3）富田英志郎：鼻副鼻腔手術における Neuroleptanesthesia の 臨床的研究. 耳鼻と臨 $28: 680 \sim 698,1982$.

4）牟田 實：鼻副鼻腔手術と局所麻酔. 耳鼻・頭頸部外科 MOOK 18 : 24 32, 1991.

5) DeConno F, Caraceni A, Gamba A, et al. : Pain measurement in cancer patients: a comparison of six methods. Pain $57: 161$ $\sim 166,1994$.

6）筒井喜美代：上顎，下顎部の手術に対するブロック．臨麻 $5: 494 \sim 499,1981$.

7）中崎和子, 若杉文吉：上䫟神経ブロック，下顎神経ブロッ ク. 外科治療 $51: 245 \sim 249,1984$.

8）増田 豊：上靧神経ブロック. ペインクリニック 20 : S192 $\sim$ S195, 1995.

9）足川力雄, 森山 寛, 内田 豊, 他 : 内視鏡下鼻内手術の 手技. 内視鏡下鼻内手術 臨床解剖と手技. $76 \sim 79$ 頁, 医 学書院, 東京, 1995.

10）那須 隆, 青柳 優: 痛みに関する耳鼻咽喉・頭頸部外科 領域の画像診断 II-Sinus pain一. ペインクリニック 26 : $778 \sim 783$.

原稿受付：平成19年 8 月 16 日 原稿採択：平成19年12月 27 日 別刷請求先 : 高橋淳人 厂632-8552 天理市三島町200 天理よろづ相談所病院耳鼻咽喉科 